\title{
Effects of Intercropping with Post-Grafting Generation of Two Ecotypes of Galinsoga parviflora on Nutrient Uptake of Lactuca sativa under Cadmium Stress
}

\author{
Keqiang Li $i^{1, a}$, Lijin Lin ${ }^{2, b}$, Wanwan Xue ${ }^{1, c}$ and Ming'an Liao ${ }^{1, d *}$ \\ ${ }^{1}$ College of Horticulture, Sichuan Agricultural University, Chengdu, Sichuan, China \\ ${ }^{2}$ Institute of Pomology and Olericulture, Sichuan Agricultural University, Chengdu, Sichuan, China \\ a627563308@qq.com, bllj800924@qq.com, c502838055@qq.com, dIman@sicau.edu.cn \\ ${ }^{*}$ Corresponding author. Keqiang Li and Lijin Lin contributed equally to this work.
}

\begin{abstract}
Keywords: Lactuca sativa; Galinsoga parviflora; Intercropping; Post-grafting generation; Nutrient uptake
\end{abstract}

\begin{abstract}
The effects of intercropping with two ecotypes of Galinsoga parviflora and their post-grafting generations on nutrient uptake of Lactuca sativa were investigated through pot experiment under the cadmium stress. The results showed that intercropping with post-grafting generation of G. parviflora of farmland ecotype as rootstock (FR) had the best effect on increasing $\mathrm{P}$ content in L. sativa roots, while intercropping with post-grafting generation of G. parviflora of mine ecotype as scion (MS) could increase the $\mathrm{P}$ content in L. sativa shoots most effectively. The root content of $\mathrm{K}$ in the monoculture L. sativa was the highest, and the highest shoots $\mathrm{K}$ content was found in the L. sativa intercropping with G. parviflora of farmland ecotype (FCK). As far as the grafting method is concerned, intercropping with post-grafting generation of G. parviflora of mine ecotypes are used as scions and farmland ecotypes as rootstocks is more conducive to L. sativa nutrient uptake. Intercropping with MS can increase soil available $\mathrm{N}$ and $\mathrm{K}$.
\end{abstract}

\section{Introduction}

Lactuca sativa, a nutrient-rich leafy vegetable, has been studied and confirmed to be adversely affected in soils contaminated by heavy metals [1]. In agricultural production, intercropping can not only increase the yield of plants, reduce the occurrence of pests and diseases, but also improve the soil environment and increase the uptake of nutrients by plants [2-3]. Galinsoga parviflora is a cadmium hyperaccumulator [4]. Different ecotypes of G. parviflora not only show differences in the absorption or tolerance of heavy metals, but they are often significantly different in response to environmental factors. Grafting is a common agronomic practice and studies have shown that grafting leads to changes in DNA methylation, produces reversible genetic changes in genomic function, and may have morphological, physiological, and ecological consequences [5-6]. Therefore, in this experiment, the Cd-hyperaccumulator G. parviflora with two ecotypes was grafted, and two ecotypes of G. parviflora and their post-grafting generations were intercrossed with L. sativa to study their effects on L. sativa nutrient uptake.

\section{Materials and Methods}

Materials. The seeds of the G. parviflora used in this experiment were collected from farms (farmland ecotype) at Ya'an Campus, Sichuan Agricultural University $\left(30^{\circ} 23^{\prime} \mathrm{N}, 103^{\circ} 48^{\prime} \mathrm{E}\right)$ and Tangjiashan Lead-Zinc Mine (mine ecotype) at Hanyuan County, Ya'an City, Sichuan Province $\left(29^{\circ} 24^{\prime} \mathrm{N}, 102^{\circ} 38^{\prime} \mathrm{N}\right)$. The climatic types and soil physicochemical properties of the two places refer to the results of Lin et al. [7]. The soil samples used in the pot experiment were paddy soil that were collected from the Chengdu campus farm of the Sichuan Agricultural University $\left(29^{\circ} 59^{\prime} \mathrm{N}, 102^{\circ} 59^{\prime}\right.$ E), $\mathrm{pH} 7.35$, organic matter $41.38 \mathrm{~g} / \mathrm{kg}$, total nitrogen $3.05 \mathrm{~g} / \mathrm{kg}$, total phosphorus $0.31 \mathrm{~g} / \mathrm{kg}$, total 
potassium $15.22 \mathrm{~g} / \mathrm{kg}$, alkaline nitrogen $165.30 \mathrm{mg} / \mathrm{kg}$, available phosphorus $5.87 \mathrm{mg} / \mathrm{kg}$, available potassium $187.03 \mathrm{mg} / \mathrm{kg}$, Cadmium not detected. The basic physical and chemical properties of the soil and the determination of heavy metal content are based on references [8]. L. sativa variety is Italian lettuce, with a year-round, resistant to twitching and heat resistance, purchased from Baofeng Seed Company.

Grafting Methods. In October 2015, the two ecotypes of G. parviflora were collected and sowed. When the seedling height is about $3 \mathrm{~cm}$ and two true leaves are spread, they are transplanted into the pot. Afterwards, two ecotypes of G. parviflora were grafted when the height of G. parviflora was about $10 \mathrm{~cm}$. The specific grafting method is as follows: (1) Farmland ecotypes are not grafted: The $G$. parviflora seedlings were transplanted directly, and then the seeds were collected for preservation as G. parviflora of farmland ecotype (FCK). (2) Mine ecotypes are not grafted: The G. parviflora seedlings were transplanted directly, and then the seeds were collected for preservation as $G$. parviflora of mine ecotype (MCK). (3) Mine ecotypes are used as rootstocks and farmland ecotypes as scions for grafting: Two ecotypes of $G$. parviflora seedlings were cut from about $6 \mathrm{~cm}$ above the ground. The mine ecotype G. parviflora seedlings were used as rootstocks and the farmland ecotype G. parviflora shoots $(4 \mathrm{~cm})$ were grafted as scions. Keep rootstock leaves and buds. After that, collect rootstock seeds as post-grafting generation of $G$. parviflora of mine ecotype as rootstock (MR) and collect scion seeds as post-grafting generation of G. parviflora of farmland ecotype as scion (FS). (4) Farmland ecotypes are used as rootstocks and mine ecotypes as scions for grafting: Two ecotypes of $G$. parviflora seedlings were cut from about $6 \mathrm{~cm}$ above the ground. The farmland ecotype $G$. parviflora seedlings were used as rootstocks and the mine ecotype $G$. parviflora shoots $(4 \mathrm{~cm})$ were grafted as scions. Keep rootstock leaves and buds. After that, collect rootstock seeds as post-grafting generation of $G$. parviflora of farmland ecotype as rootstock (FR) and collect scion seeds as post-grafting generation of G. parviflora of mine ecotype as scion (MS). During the grafting process, the soil used was free from heavy metal pollution.

Experimental Design. The experiment was conducted in the greenhouse of the Sichuan Agricultural University in Chengdu campus. Air-dried soil $(2.5 \mathrm{~kg})$ was weighed and placed into each polyethylene pot ( $21 \mathrm{~cm}$ high, $20 \mathrm{~cm}$ diamete). Cd was added to the soil samples as analytical reagent $\mathrm{CdCl}_{2} \cdot 2.5 \mathrm{H}_{2} \mathrm{O}$ at the concentration of $10 \mathrm{mg} / \mathrm{kg}$ [9], and then the soil was thoroughly mixed. Natural balance for 4 weeks, occasionally turning soil mixing, so that the soil is fully mixed. In March 2016, the collected G. parviflora seeds and purchased L. sativa seeds were sown and nursed. In April 2016, when the seedlings of $G$. parviflora were about $3 \mathrm{~cm}$ high and 2 true leaves were unfolded, they were transplanted into pots with L. sativa. Seven treatments were applied in the experiment: L. sativa monoculture (CK), intercropping with FCK, intercropping with $\mathrm{MCK}$, intercropping with FR, intercropping with MR, intercropping with FS, intercropping with MS. Monoculture treatment four $L$. sativa per pot, intercropping treatments were planted with three L. sativa and one G. parviflora per pot. Repeat 4 times for each treatment, completely randomized design with $15-\mathrm{cm}$ spacing between pots, timely weeding, pest control, and no disease. After $60 \mathrm{~d}$ (June 2016), the entire plants of each pot were harvested, roots and shoots were separated, washed, dried, crushed, and the $\mathrm{P}$ and $\mathrm{K}$ content were determined [8]. Then collect the soil, air dry, crush, measure the soil alkaline N, available P and available K content [8].

Statistical Analyses. Statistical analyses were conducted using SPSS 13.0 statistical software (IBM, Chicago, IL, USA). Data were analyzed by one-way analysis of variance with least significant difference (LSD) at the $\mathrm{P}=0.05$ confidence level.

\section{Results and Discussion}

P Content in $L$. sativa. Table 1 shows that under cadmium stress, the $\mathrm{P}$ content in $L$. sativa in 
intercropping with FCK, FR, MR and MS were significantly higher than monoculture $(P<0.05)$. And the root P content in L. sativa was increased by $21.34 \%, 38.21 \%, 17.87 \%$ and $14.39 \%$ compared to the monoculture. In terms of shoots, compared with monoculture, except for intercropping with FS, which significantly reduced the $\mathrm{P}$ content in shoots of $L$. sativa, other treatments significantly increased the $\mathrm{P}$ content in in shoots of L. sativa. Furthermore, the $\mathrm{P}$ content in shoots of L. sativa intercropping with FCK, MCK, FR, MR and MS increased by $23.54 \%, 7.53 \%, 19.77 \%, 14.12 \%$ and $38.04 \%$ compared with the monoculture.

Table $1 \mathrm{P}$ content in L. Sativa

\begin{tabular}{|c|c|c|}
\hline Treatments & $\begin{array}{c}\text { Roots } \\
(\mathrm{mg} / \mathrm{g})\end{array}$ & $\begin{array}{c}\text { Shoots } \\
(\mathrm{mg} / \mathrm{g})\end{array}$ \\
\hline CK & $0.403 \pm 0.022 \mathrm{c}$ & $0.531 \pm 0.007 \mathrm{e}$ \\
\hline FCK & $0.489 \pm 0.026 \mathrm{~b}$ & $0.656 \pm 0.027 \mathrm{~b}$ \\
\hline MCK & $0.449 \pm 0.004 \mathrm{bc}$ & $0.571 \pm 0.006 \mathrm{~d}$ \\
\hline FR & $0.557 \pm 0.017 \mathrm{a}$ & $0.636 \pm 0.015 \mathrm{bc}$ \\
\hline MR & $0.475 \pm 0.022 \mathrm{~b}$ & $0.606 \pm 0.011 \mathrm{c}$ \\
\hline FS & $0.332 \pm 0.017 \mathrm{~d}$ & $0.467 \pm 0.002 \mathrm{f}$ \\
\hline MS & $0.461 \pm 0.029 \mathrm{~b}$ & $0.733 \pm 0.006 \mathrm{a}$ \\
\hline
\end{tabular}

Different lowercase letters indicate significant differences based on one-way analysis of variance in SPSS 17.0 followed by the least significant difference test $(P<0.05)$. $\mathrm{CK}=$ monoculture, $\mathrm{FCK}=$ intercropping with $G$. parviflora of farmland ecotype, $\mathrm{MCK}=$ intercropping with G. parviflora of mine ecotype, $\mathrm{FR}=$ intercropping with post-grafting generation of $G$. parviflora of farmland ecotype as rootstock, MR = intercropping with post-grafting generation of $G$. parviflora of mine ecotype as rootstock, FS = intercropping with post-grafting generation of $G$. parviflora of farmland ecotype as scion, MS = intercropping with post-grafting generation of $G$. parviflora of mine ecotype as scion. Same as below.

K Content in $L$. sativa. Table 2 shows that under the cadmium stress, the root $\mathrm{K}$ content of all intercropping treatments in L. sativa was significantly lower than that of the control (monoculture) $(P$ $<0.05)$. In terms of shoots, intercropping with FR and FS reduced the shoots K content of L. sativa compared to monoculture. However, $\mathrm{K}$ content in the shoots of L. sativa intercropping with FCK, MCK, MR, and MS was significantly increased compared with the monoculture, which increased by $33.25 \%, 16.66 \%, 24.77 \%$, and $31.17 \%$, respectively.

Table 2 K content in L. Sativa

\begin{tabular}{|c|c|c|}
\hline Treatments & $\begin{array}{c}\text { Roots } \\
(\mathrm{mg} / \mathrm{g})\end{array}$ & $\begin{array}{c}\text { Shoots } \\
(\mathrm{mg} / \mathrm{g})\end{array}$ \\
\hline CK & $44.570 \pm 1.127 \mathrm{a}$ & $74.016 \pm 0.211 \mathrm{e}$ \\
\hline FCK & $20.355 \pm 0.705 \mathrm{~cd}$ & $98.630 \pm 0.071 \mathrm{a}$ \\
\hline MCK & $19.607 \pm 0.352 \mathrm{~d}$ & $86.348 \pm 0.388 \mathrm{~d}$ \\
\hline FR & $21.252 \pm 0.564 \mathrm{c}$ & $70.379 \pm 0.423 \mathrm{f}$ \\
\hline MR & $19.308 \pm 0.634 \mathrm{~d}$ & $92.352 \pm 0.352 \mathrm{c}$ \\
\hline FS & $28.890 \pm 0.092 \mathrm{~b}$ & $69.682 \pm 1.409 \mathrm{f}$ \\
\hline MS & $12.183 \pm 0.423 \mathrm{e}$ & $97.085 \pm 0.705 \mathrm{~b}$ \\
\hline
\end{tabular}

Available Nutrients in Soil. Table 3 shows that in cadmium-contaminated soil, the content of soil alkaline $\mathrm{N}$ in L. sativa intercropping with MS was significantly higher than that of the monoculture, and it was $11.25 \%$ higher than that of the monoculture, but the content of alkaline $\mathrm{N}$ in other treatments was not significantly different from the monoculture $(P>0.05)$. Compared with the monoculture, L. sativa intercropping with the two ecotypes of G. parviflora and their post-grafting generations had no significant effect on the content of available $\mathrm{P}$ in the cadmium-contaminated soil $(P>0.05)$. Under the condition of cadmium pollution, the available $\mathrm{K}$ content in the soil of $L$. sativa intercropping with MS increased by $8.15 \%$ compared with the monoculture $(P<0.05)$, and there was no significant difference in available $\mathrm{K}$ content between the other treated soils and the control (monoculture). 


\section{Conclusions}

Under the cadmium stress, after six intercropping treatments, the results showed that intercropping with two ecotypes of $G$. parviflora and their post-grafting generations could affect the nutrient uptake of L. sativa. In general, with the exception of intercropping with FS, other treatments can improve the nutrient uptake of L. sativa. Among them, intercropping with FR had the best effect on increasing $\mathrm{P}$ content in L. sativa roots, while intercropping with MS could increase the $\mathrm{P}$ content in L. sativa shoots most effectively. For $\mathrm{K}$ content, the root content of $\mathrm{K}$ in the monoculture L. sativa was the highest, and the highest shoots K content was found in the L. sativa intercropping with FCK. As far as the grafting method is concerned, intercropping with post-grafting generation of G. parviflora of mine ecotypes are used as scions and farmland ecotypes as rootstocks is more conducive to L. sativa nutrient uptake. On the other hand, intercropping with MS can increase soil available $\mathrm{N}$ and $\mathrm{K}$. It may be that the root exudates produced by the L. sativa intercropping with G. parviflora affected the physicochemical properties of the plant rhizosphere soil, increased soil enzyme activities in the rhizosphere soil, and improved soil fertility. The change of soil available nutrient content is also one of the reasons that affect the absorption of $L$. sativa nutrients.

Table 3 Available nutrients in the soil

\begin{tabular}{|c|c|c|c|}
\hline Treatments & $\begin{array}{c}\text { Alkaline nitrogen } \\
(\mathrm{mg} / \mathrm{kg})\end{array}$ & $\begin{array}{c}\text { Available phosphorus } \\
(\mathrm{mg} / \mathrm{kg})\end{array}$ & $\begin{array}{c}\text { Available potassium } \\
(\mathrm{mg} / \mathrm{kg})\end{array}$ \\
\hline CK & $54.741 \pm 3.762 \mathrm{~b}$ & $1.211 \pm 0.070 \mathrm{a}$ & $91.365 \pm 1.756 \mathrm{~b}$ \\
\hline FCK & $56.375 \pm 1.520 \mathrm{ab}$ & $1.135 \pm 0.023 \mathrm{a}$ & $87.651 \pm 0.014 \mathrm{~b}$ \\
\hline MCK & $58.975 \pm 1.237 \mathrm{ab}$ & $1.107 \pm 0.070 \mathrm{a}$ & $87.641 \pm 3.511 \mathrm{~b}$ \\
\hline FR & $54.950 \pm 1.485 \mathrm{ab}$ & $1.080 \pm 0.116 \mathrm{a}$ & $87.641 \pm 3.511 \mathrm{~b}$ \\
\hline MR & $59.325 \pm 2.227 \mathrm{ab}$ & $1.097 \pm 0.077 \mathrm{a}$ & $88.882 \pm 1.756 \mathrm{~b}$ \\
\hline FS & $54.600 \pm 3.960 \mathrm{~b}$ & $1.129 \pm 0.016 \mathrm{a}$ & $87.646 \pm 0.007 \mathrm{~b}$ \\
\hline MS & $60.900 \pm 0.990 \mathrm{a}$ & $1.138 \pm 0.074 \mathrm{a}$ & $98.813 \pm 1.756 \mathrm{a}$ \\
\hline
\end{tabular}

\section{Acknowledgements}

This work was financially supported by the Application Infrastructure Project of Science and Technology Department of Sichuan Province (2016JY0258).

\section{References}

[1] F. Mehmood, A. Rashid, T. Mahmood and L. Dawson: Chemosphere Vol. 90 (2013), p. 1805.

[2] X. Xiao, Z. Cheng, H. Meng, L. Liu, H. Li and Y. Dong: PLoS One Vol. 8 (2013), p. e62173.

[3] H.H. Dai, X.F. Hu, Y.Y. Cao, M.Y. Yang and J. Wang: Acta Pedologica Sinica Vol. 52 (2015), p. 911.

[4] L. Lin, Q. Jin, Y. Liu, B. Ning, M. Liao and L. Luo: Environmental Toxicology and Chemistry Vol. 33 (2015), p. 2422.

[5] R.A. Rapp and J.F. Wendel: New Phytologist Vol. 168 (2010), p. 81.

[6] A. Fossey: Southern Forests: a Journal of Forest Science Vol. 71 (2009), p. 121.

[7] L.J. Lin, M.A. Liao, L.Y. Mei and J. Cheng: Chinese Journal of Eco-Agriculture Vol. 21 (2013), p. 1565.

[8] S.D. Bao: Agrochemical Soil Analysis (China Agriculture Press, Beijing 2000).

[9] F.Y. Tang, L.J. Lin, D.Y. Yang, M.A. Liao, Q.Q. Ma, C.Y. Liu and J. He: Chinese Journal of Soil Science Vol. 47 (2016), p. 207. 